\title{
LAND AS A SOURCE OF REVENUE MOBILISATION FOR LOCAL AUTHORITIES IN GHANA
}

\author{
S.O. Asiama \\ College of Architecture and Planning \\ Kwame Nkrumah University of Science and Technology, \\ Kumasi
}

\begin{abstract}
Local government finance poses problems to many governments in the developing world. This is notwithstanding the fact that local authorities are at the forefront of local development efforts. In Ghana, the central government is enjoined by the country's constitution to devolve at least five percent of the national revenue to local authorities annually. For many local authorities, this has become the main source of finance. Though there are other sources of finance available to the local authorities, these have been deemphasised by most local authorities. The paper postulates that the land resources of the local authorities provide a veritable source of local revenue which has not been fully tapped by the authorities. Apart from the property rate which all local authorities in the country levy, little attention is paid to the potential of the land resources of the local authorities as sources of revenue. The paper presents some opportunities available to the local authorities to raise money from their land resources.
\end{abstract}

Keywords: Land, Local authorities, District Assemblies, Revenue generation

\section{INTRODUCTION}

Finance for local development poses problems to many governments in the Third World. This is because while the local authority remains the major partner of the central government in the provision of services at the local level, central government finance is often limited and inadequate funds can be devolved on the local government authorities. For many of such authorities, therefore, finance has had to be generated at the local level and the ingenuity of many of such authorities has demonstrated the fact that there is no end to the number of sources of such revenues.

In Ghana, the Local Government Act, 1993 (Act 462) lists ten main sources of revenue for local authorities. The sub-heads under these sources are not exhaustive and local authorities have often gone to great lengths to eke out their revenues. In addition, local authorities are permitted, under Section 88 of the Act, to raise loans or obtain overdrafts where this is deemed necessary. Local authorities also receive monies under the District Assemblies Common Fund Act, 1993 (Act 455) for projects within their areas of authority.

While receipts from the Common Fund constitute a major, and in many local authorities the highest, source of revenue, landed property remains the single largest and the most reliable source of locally generated funds. This is not withstanding the fact that the potential of land as a source of revenue generation has not been exploited by many District Assemblies and there has been a concentration on the property rate as the main source of income from property. There is no doubt that if local authorities took advantage of the numerous opportunities offered by land as a source of revenue, they could significantly increase their revenue base and rely less on the Common Fund.

The paper examines the sources of revenue generation in some District Assemblies and shows that the Common Fund remains the single largest source of income for the Assemblies. The performance of land as a source of revenue generation is discussed and this is related to the other sources of locally generated revenue. The characteristics of land as a local resource making it a good source of revenue generation are discussed. The influence of the local authority in creating land based wealth in the local area is discussed and this leads to a discussion of the opportunities land offers the local authorities to raise revenues for local development.

\section{TRADITIONAL SOURCES OF FINANCE}

The Sixth Schedule of the Local Government Act, 1993 (Act 462) lists ten main headings under which the local authority could generate revenue. Under each heading are a number of sources. For example, under 
Fees, there are fourteen separate items on which the local authority could collect revenues while under Licences, there are fifteen separate items.

In spite of the large number of revenue sources, many local authorities have concentrated on a few perhaps because they find them easier targets. Added to this have been the poor collection methods of many local authorities, which results in many authorities failing to collect their estimated revenues. Table 1 shows the performance of local authorities in revenue collection per region.

Table 1: Revenue Performance of District Assemblies per Region, 1999

\begin{tabular}{lccc}
\hline Region & Estimated Revenue & $\begin{array}{c}\text { Actual Revenue } \\
\text { Collected } \\
\boldsymbol{c}\end{array}$ & $\begin{array}{c}\text { Percentage } \\
\text { Shortfall }\end{array}$ \\
\hline Central & $23,332,600,000$ & $17,035,700,000$ & 27 \\
Eastern & $29,669,800,000$ & $19,579,600,000$ & 34 \\
Brong Ahafo & $26,407,300,000$ & $17,718,600,000$ & 33 \\
Ashanti & $31,767,200,000$ & $22,623,300,000$ & 29 \\
Western & $27,826,200,000$ & $18,244,300,000$ & 34 \\
Volta & $22,418,600,000$ & $15,541,600,000$ & 31 \\
Northern & $20,937,900,000$ & $16,852,300,000$ & 20 \\
Upper East & $12,879,800,000$ & $8,695,500,000$ & 32 \\
Upper West & $9,954,700,000$ & $5,552,700,000$ & 44 \\
Greater Accra & $18,370,500,000$ & $16,116,800,000$ & 12 \\
\hline Source: Ministy & & & \\
\hline
\end{tabular}

Source: Ministry of Local Government

The percentage shortfalls are more significant in the rural District Assemblies. Table 3 shows revenue mobilisation performance in some selected rural districts across the country in 1999. One district has been randomly selected from each Region of the country and the order of the Regions follows the same order as in Table 2.

Table 2: Revenue Performance of some Rural Districts, 1999

\begin{tabular}{lccc}
\hline District & $\begin{array}{c}\text { Estimated } \\
\text { Revenue } \\
\text { Assin }\end{array}$ & $\begin{array}{c}\text { Actual Revenue } \\
\text { Collected } \\
\text { Birim South }\end{array}$ & $\begin{array}{c}\text { Percentage } \\
\text { Shortfall }\end{array}$ \\
Techiman & $3,459,000,000$ & $1,774,400,000$ & 49 \\
Ahafo Ano North & $3,633,200,000$ & $1,690,300,000$ & 53 \\
Wassa West & $3,384,000,000$ & $2,487,300,000$ & 54 \\
Akatsi & $2,230,000,000$ & $1,166,200,000$ & 48 \\
Gushegu Karaga & $1,230,900,000$ & $535,700,000$ & 56 \\
Bawku West & $1,799,500,000$ & $746,400,000$ & 59 \\
Nadowli & $2,543,600,000$ & $920,000,000$ & 64 \\
Dangme West & $2,000,000,000$ & $1,326,100,000$ & 34 \\
\hline
\end{tabular}

Source: Ministry of Local Government 
To mitigate the effects of the poor revenue generation of the local authorities, the 1992 Constitution created the District Assemblies Common Fund and enjoined central government to pay five percent of national revenue annually into it. This amount is shared among the local authorities in accordance with a formula determined by Parliament. For many local authorities the Common Fund has become the single major source of revenue. The example of the Ejisu - Juaben District Assembly is symptomatic of many local authorities as shown in Table 3.

Table 3: Ejisu-Juaben District Assembly: Relationship between Common Fund Revenues and Total Revenue

\begin{tabular}{ccc}
\hline Year & $\begin{array}{c}\text { Common Fund } \\
\boldsymbol{c}\end{array}$ & $\begin{array}{c}\text { Percentage Of } \\
\text { Total Revenue }\end{array}$ \\
\hline $\mathbf{1 9 9 8}$ & $987,100,000.00$ & 91 \\
$\mathbf{1 9 9 9}$ & $1,134,000,000.00$ & 92 \\
$\mathbf{2 0 0 0}$ & $1,588,000,000.00$ & 90 \\
$\mathbf{2 0 0 1}$ & $5,021,000,000.00$ & 96 \\
\hline
\end{tabular}

Source: Kyekye et al 2002:49

The Table shows that revenues from the Common Fund have progressively risen from $91 \%$ of total revenue to $96 \%$ in the period under review.

Revenue from land in most local authorities is derived from their share of ground rents from leases of stool land granted in their areas. This is usually very small and constituted only about one per cent of the total revenue of the Accra Metropolitan Assembly in each year from 1999 to 2001 (Ayivi, et al. 2002:65). In the smaller local authorities, particularly those adjoining larger urban centres, revenue from land usually constitute a significant proportion of revenues. This is due to the fact that other revenues are generally low and also because those near the large urban centres serve as dormitory towns and land acquisition is high in such areas, giving rise to high revenues from land. It needs to be mentioned, however, that the local authorities hardly play any role in the generation of such revenues as the Office of the Administrator of Stool Lands simply collects stool land revenues and disburses them to the District Assemblies and other beneficiaries in accordance with Article 267 (6) of the Constitution. In the Ejisu Juaben District Assembly, revenue from land constituted almost a third of locally generated revenue, as shown in Table 4. This is because land acquisition is high in the District as many residents of Kumasi now purchase land in the District for their homes.

Table 4: Ejisu-Juaben District Assembly:

Relationship between Total Locally Generated Revenues and Revenue from Land

\begin{tabular}{ccc}
\hline Year & $\begin{array}{c}\text { Locally } \\
\text { Generated } \\
\text { Revenue }\end{array}$ & $\begin{array}{c}\text { Land Revenue } \\
\%\end{array}$ \\
\hline $\mathbf{1 9 9 9}$ & $102,399,542.00$ & 24.7 \\
$\mathbf{2 0 0 0}$ & $174,457,869.00$ & 29.1 \\
$\mathbf{2 0 0 1}$ & $202,334,137.00$ & 32.6 \\
\hline
\end{tabular}

Source: Kyekye et al 2002:51

\section{LAND AS A LOCAL RESOURCE}

Land has some unique characteristics, which distinguish it from other goods in the economy (DarinDrabkin, 1977) and make it a good resource for revenue generation by local authorities. These can be summarised as: 
a) Land is physically undepreciable and is not influenced by time: one may argue that where land has been developed, the development may depreciate over time while the bare land itself is indepreciable. In some cases the depreciation in the structure may occasion an increase in the value of land, by creating a residual value in the land, because of the expectation of a change in use when a new and modern structure commanding a higher price may be erected.

b) Land is fixed in location: this makes land a permanent local asset. Thus, while the use of land can be altered to meet the demands of the day, the land itself cannot be transported outside the locality.

c) Land is limited in supply: its supply cannot be physically increased (except in reclamation programmes). Thus, as the demand for land increases, its price generally increases.

d) Land is a store of value and a basis for savings. Land values tend to increase ahead of the rate of inflation making land attractive as an investment and spawning land speculation.

e) Land is a means of production and, thus, a store of wealth. It can be used to create wealth when it plays a part in production.

These characteristics make land a unique resource for local authorities. The benefits of land holding are often locally based and, thus, accessible to the local authorities, not only for taxation purposes but also for enhancing the living conditions of the local people through spatial and economic planning.

If these characteristics of land are to be harnessed by local authorities for achieving local development objectives, it is necessary to develop land management practices, which will aid the local authorities.

In Ghana local authorities have traditionally had very little control over their land resources. This is because land ownership and administration have been kept in the hands of traditional authorities who have traditionally had the authority to alienate lands and sometimes, even influence the use of land. In the few cases where land in the local authority area is held or controlled by government through the Lands Commission, local authorities have again, had very little control of land management practices. Local authorities have been reduced to being mere recipients of revenue from land in the form of a proportion of the ground rents that are generated from stool lands.

\section{LOCAL AUTHORITIES AND THE \\ LAND MARKET}

Like the market in all commodities the forces of supply and demand influence the land market and determine price. This general principle is often affected by the peculiarities of the land market and the particular characteristics of a locality greatly influence the market in land owing to the fact that land is a local commodity. To this extent the activities of local authorities could have significant effects on the land market by influencing the local economy. Unfortunately, this has often not been recognised.

It is well known that higher land prices do not always lead to increases in supply and, in fact, sometimes lead to a reduction in prices. This is because landowners, in expectation of the prices rising further, may actually withhold their land from the market. Landowners often have no production costs and, in many cases, particularly in Ghana, no holding costs; it does not cost them anything to leave the land undeveloped while they wait for prices to rise. This is particularly so in the peri-urban areas, at the interface of agricultural and residential land uses. Landowners can do this because they are in a monopoly situation; they can bid their time in expectation of higher profits when prices rise. In practice, these price increases often depend upon the speed with which the local authority extends infrastructure to the area.

The local authority in many developing countries is a fulcrum around which development revolves. The pace of infrastructure provision, such as access roads, drainage facilities, water, etc., often determines the direction and rate of growth in the urban area. It also serves to enhance demand for land in those areas and often lead to increments in land values.

The local authority also influences the land market in its willingness, through its planning machinery, to grant applications for change of use. Where landowners are confident that the local authority would permit or, as it so often happens in Ghana, turn a blind eye to the change of use of land, they tend to increase land values in anticipation of the expected use. Thus, in Accra and Kumasi, residential land values tend to be very high, particularly along the major roads, because landowners know that they can always convert such lands to commercial use.

As city residents become affluent they tend to re-locate outside the overcrowded city centre and into the 
suburbs. Sometimes, owing to their influence in the local authority and other service providing agencies, they manage to get infrastructure to such areas greatly enhancing land values in the locality.

\section{CURRENT USE OF LAND IN LOCAL AUTHORITY FINANCE}

The implications of the foregoing have been lost on many local authorities in the country. As it is the case in many former British colonies in Africa, there has been an over-reliance on the property rate as the main source of revenue from land (Murray 1966:57). This may be due to the advantages enjoyed by the property rate as a local tax.

In addition, the property rate has been seen to satisfy the four qualities of a good tax (i.e. fairness, administrative feasibility, political acceptability, and simplicity) in many societies (Asiama 1982:33).

The property rate, as it is being applied in the country, however, does not help the local authorities to derive much benefit from the land resources available to the authorities in their areas of operation.

The basis of assessing the property rate in Ghana is the Depreciated Replacement Cost. Section 96 (9) of the Local Government Act, 1993 (Act 462) provides:

"Subject to Subsection (11) of this Section, the rateable value of premises shall be the replacement cost of the buildings, structures and other development comprised in the premises after deducting the amount which it would cost at the time of the valuation to restore the premises to a condition in which they would be as serviceable as they were when new; except that the rateable value shall not be more than fifty percent of the replacement cost for the premises of an owner occupier and shall not be less than seventy-five per cent of the replacement cost in all other cases"

In adopting the replacement cost as the basis of valuation, the Act makes it impossible for the local authority to derive the benefits of land value increments, which, as we have seen, are often the result of local authority action. Activities in the land market have little implications for local authority finance. Two identical properties, one located in a first class area generating rent in foreign currency and another located in a third class area, in the same city will have the same replacement cost and hence the same rateable values. In differentiating the rate payable between them, the local authority applies differential rate imposts, which are supposed to take account of their advantages of location. Unfortunately, local authorities are unable to develop rate imposts, which adequately address the locational advantages of properties on their Valuation Lists and have often adopted arbitrary rates. This often creates both vertical and horizontal inequities in the assessment of the rate.

Again, by prescribing the Replacement Cost as the basis of valuation, the Act excludes land from liability under the tax. This means that while a landowner holds on to his land without developing it, he is not liable to pay the rate. When he develops the land, however, he becomes liable. Thus, it is to his advantage that the land remains undeveloped. This is a disincentive to development and encourages land speculation.

By exempting unoccupied properties from liability under the property rate, the Act (Section 99(4)) has operated to exclude speculators who keep their properties vacant while waiting for a good price, from paying the property rate. For example, in the good areas of Accra such as the Airport, it is common to find vacant houses whose owners are waiting for tenants who will pay foreign exchange. During the period of waiting, the landlord does not pay property rates though local authority infrastructure and services such as roads, drainage, etc., are provided to the property and must be paid for.

\section{LAND AS A LOCAL SOURCE OF}

\section{REVENUE - THE OPPORTUNITIES}

Land is a veritable source of revenue for local authorities which, when exploited, would greatly enhance the revenue base of the authorities. Unfortunately, local authorities in Ghana have failed to exploit the potential of their land revenue resources in this sense. In this section, some of the opportunities are discussed.

The Property Rate

The foregoing discussion shows that the property rate, as currently operated, does not afford the local 
authorities the opportunity to maximise their returns from the tax. To make the property rate more effective, it should be possible for the basis of valuation to be changed to the open market value. When this is done, it would be possible to base the rate on either the annual values or the capital values of the properties. In the good areas of Accra and other urban centres, enough market data exist to support the use of the open market as a basis for assessing the rate. When this is done the Accra Metropolitan Assembly will be able to levy rates that are commensurate with the earning capacity of the properties. Again, the use of the open market as a basis will make it possible to levy land and, therefore, make land speculation less profitable. Again, this would greatly enhance local revenues.

It is instructive to note that the Local Government Act, 1993 (Act 462) provides that "the Minister may by legislative instrument prescribe either generally or in respect of any particular district a basis for the assessment of rateable values of the premises". Thus, the legislative infrastructure already exists.

\section{Taxation of Land Value}

As an alternative to the property rate, local authorities could base their assessment of taxes on land values only. This means that improvements on land would be ignored and the tax levied on land. This would make the assessment less cumbersome and faster as mass valuations could be carried out. It would discourage speculation as the tax could be made to fall more heavily on vacant land. This tax will also capture increases in land value that occur in the economy and which are not the result of investment decisions of landowners (what the classical political economists call unearned increments to land value). In other words, society would take for itself, part of the income it creates in land for landowners and would lead to increased revenue for the local authorities.

\section{Betterment Levies}

The betterment levy is a tax, which has been little used - perhaps because it is thought to be cumbersome to assess and operate. In Ghana, though betterment levies have been in existence since 1945 when the Town Planning Ordinance (Cap 84) was passed, it has never been levied. The basis of the tax is that where a public body, like the local authority, carries out any public project which leads to increases in land values, a tax should be levied on the increment in land values which is a direct result of the public investment. This levy helps to defray some of the costs of the project and, thus, creates more funds for re-investment in more public projects. Such land value increments are created everyday in our cities and are particularly apparent in the peri-urban areas. For example, every time a road is constructed to a hitherto inaccessible part of the city, land values increase significantly, sometimes in multiples. This is public investment for which landowners enjoy the profits. In Accra, the construction of the motorway extension and the effect it had on opening up areas like Kwashieman and the subsequent increase in land values is too obvious to recount. Again, the construction of the Mental Hospital at Pantang, a hitherto inaccessible part of the city, had the effect of increasing the land values almost tenfold because a road was constructed, water and electricity were also provided and the place opened up to developers (Asiama, 1980). In Kumasi, when buying land on the outskirts of town, there are often two prices quoted - one for where there is water and electricity and the other for where these services do not exist. The difference is betterment and part of it rightly belongs to the public body, which provided the water and the electricity.

In newly developing areas, the betterment levy accrues, not to individuals but to the traditional landowners who own large expanses of land. They do not pass on any of such income to the state, even as income taxes.

\section{Provision of Serviced Land Under Act 462}

The Local Government Act, 1993 (Act 462) provides in Section 84 that a local authority could purchase land, service it, and re-allocate it to be developed by prospective public or private developers to promote development. Local authorities are therefore empowered to be actively involved in the development of their areas and to also raise money. Practically one can say that this is a blank cheque handed to the local authorities by the state and how much money the authorities can raise depends on them. This is because the Act states that even if the land owners are unwilling to sell or part with possession of the land, the Authority could apply for the use of the government's powers of eminent domain for the land to be acquired for them. And what is more, the local authority does not even have to pay for the compensation up-front. The Government pays and receives a refund later - perhaps after the local authority has reallocated the serviced plots and earned its profits. Unfortunately, to date, no local authority has taken advantage of these provisions. 


\section{Partnerships with Landowners}

Local authorities should be proactive and not only expect to raise revenue from land through taxation. Though they do not control land within their areas of authority, local authorities could enter into partnerships with the traditional landowners to facilitate land development. Experience has shown that traditional landowners lack the means to provide infrastructure on their land prior to alienating such lands. But they know that the provision of infrastructure would greatly enhance the values of their lands. Local authorities could arrange with the traditional authorities as partners in development and provide infrastructure on the land prior to the alienation of such lands and share the increments in land values with the landowners in an agreed proportion. The landowner would be at an advantage as he would get a higher return from the land than he would if he alienated the land in its undeveloped state.

For the local authority, the benefits could be threefold. First, the authority would be able to generate revenue because after deducting the cost of the investment in the infrastructure and sharing the excess with the landowners, there will be substantial returns, which the authority could use in its operations. Secondly, the authority would be ensuring for itself a better environment and better developed neighbourhoods, which is the goal of every local authority. Thirdly, well-developed neighbourhoods mean more money in terms of property rates for the local authority.

\section{CONCLUSION}

This paper has examined how local authorities can use land as a source of raising money for local development. The ideas expressed in this paper have been drawn from experiences in many countries. Surely, there is no perfect method but a combination of the methods discussed in this paper could help local authorities in Ghana to realise their dreams of creating the congenial and hospitable cities that we all crave for.

\section{REFERENCES}

Andrews, R. B. (ed) (1972). Urban Land Use Policy, The Free Press, New York,

Asiama, S.O (1980). Social Analysis, Urbanisation and Land Reform in Ghana Ph.D. Dissertation, University of Birmingham, U.K.

Asiama, S.O. (1982). Land Taxation in Ghana, Land Administration Research Centre, KNUST, Kumasi.

Asiama, S.O. (1992). Land Management in Kumasi, Report prepared for the World Bank, October 1989.

Ayee, J.R.A. (1992) "Decentralisation and Effective Government: the Case of Ghana's District Assemblies" African Insight Vol. 22 No. 1: 49-56

Ayee, J.R.A. (1995). Financing Sub-National Governments in Ghana: The District Assemblies Common Fund, International Journal for Regional and Federal Studies Vol. 5 No. 3.

Ayivi, S., Nortey, G., Abankwa, P. Comnashar E. O. (2002). Financial Performance of District Assemblies, 1999-2001: Effects and Policy Implications, Case Study: Accra Metropolitan Assembly and Cape Coast Municipal Assembly. Unpublished Dissertation, Institute of Land Management and Development KNUST, Kumasi, Ghana

Darin-Drabkin, H. (1977). Land Policy and Urban Growth, Pergamon Press, Oxford,

Kyekye, F.D., Winful, P.E., Blewushie S.J., Cudjoe, F., Addo, C. (2002). The Problems and Challenges of Managing Decentralisation - a Case Study of the Ejisu-Juaben District. Unpublished Dissertation, Institute of Land Management and Development KNUST, Kumasi, Ghana

Ministry of Local Government, (1999). Annual Estimates of District Assemblies, 1999. Ministry of Local Government, Accra.

Murray, J.F.N. (1966). "United Nations Assistance in Establishing Tax Systems", in 1966 International Seminar on Land Taxation, Land Tenure, and Land Reform in Developing Countries, University of Hartford, 48-64. 